\author{
Research Article
}

\title{
On Social Enterprises and Social Entrepreneurship: An Extension
}

Leandro da Silva Nascimento ${ }^{1}$

Viviane Santos Salazar ${ }^{1}$

${ }^{1}$ Universidade Federal de Pernambuco, Recife, PE, Brazil

Received 30 January 2019. This paper was with the authors for two revisions. Accepted 11 July 2020. First published online 17 July 2020.

Marcos Hashimoto was the associate editor for this article.

Editor-in-chief: Carlo Gabriel Porto Bellini

Editorial assistants: Kler Godoy and Simone Rafael 


\begin{abstract}
Research on social entrepreneurship still lacks theoretical depth, as well as the analysis of the antecedents that lead to the emergence of social enterprises. Seeking to advance such discussion, this paper aims to analyze if and how the conceptual model for analysis of social entrepreneurship antecedents proposed by Jiao in 2011 is empirically supported. Thus, semi-structured interviews with ten Brazilian social entrepreneurs were conducted. From the results, the existence of a new antecedent not described in the conceptual model developed by Jiao was identified, and a framework for analysis of the antecedents that lead to the emergence of social enterprises is being proposed in this paper. The framework elaborated from cases present in an emerging economy that has several social problems also points to analytical inconsistencies in Jiao's model. Besides allowing the theoretical advance about the initial stage of social enterprises formation, this paper also contributes presenting relations that help minimize the theoretical misunderstanding about the conceptualization of social entrepreneurship, generating a clarified definition. In addition, an agenda with directions for future research on social enterprises and social entrepreneurship is proposed.
\end{abstract}

Keywords: social enterprise; antecedents; social entrepreneurship; definition.

JEL code: L31. 


\section{Introduction}

A social enterprise is a new organizational model whose focus is on the creation of social impact as a means to mitigate the various social problems existing in the contemporary world (Ashraf, Razzaque, Liaw, Ray, \& Hasan, 2019; Chell, Nicolopoulou, \& Karataş-Özkan, 2010). Even though they are directed towards social value propagation, social enterprises have the same functioning structure that is present in traditional enterprises, with a focus on generating profit in all ways (Yunus, Moingeon, \& Lehmann-Ortega, 2010). Thus, social enterprises are hybrid organizations that seek a social mission and are sustained by operations and commercial activities, which require a productive balance between financial and social purposes (Battilana, Sengul, Pache, \& Model, 2014; Shaw \& Carter, 2007; Wry \& York, 2017; Zahra, Rawhouser, Bhawe, Neubaum, \& Hayton, 2008).

A social enterprise emerges as a solution to deal with social problems that certain individuals experience in their local realities (Ip, Wu, Liu, \& Liang, 2017). Although all the inhabitants of a community witness the social and environmental difficulties of that place, only a few individuals with specific values, capabilities, and abilities are attracted to social entrepreneurship (Chandra \& Shang, 2017), searching for innovative opportunities and responses to create social value (Zahra, Gedajlovic, Neubaum, \& Shulman, 2009). Thus, personal values and motivations may induce particular individuals to create social enterprises (Hockerts, 2017; Ruskin, Seymour, \& Webster, 2016) as a means to overcome social problems. Going beyond, there are certain antecedents that lead certain individuals to develop social enterprises (Cavazos-Arroyo, PuenteDiaz, \& Agarwal, 2017; Jiao, 2011; Shumate, Atouba, Cooper, \& Pilny, 2014).

However, the understanding of the antecedents of social enterprises is still little explored and needs further investigation (Foster \& Grichnik, 2013; Germak \& Robinson, 2014; Ip, Liang, Wu, Law, \& Liu, 2018). It has relevance to both academic and practical perspectives (Baierl, Grichnik, Spörrle, \& Welpe, 2014), as the comprehension of the antecedents leads to the motivation and engagement of actors in social entrepreneurship actions from both perspectives (Hockerts, 2017). With regard to the antecedents that lead to the emergence of social enterprises, Jiao (2011) proposed a conceptual model composed by five antecedents; this model is theoretical and, according to the author, future research can empirically apply the model for understanding the antecedents.

This paper aims to analyze if and how the conceptual model for analysis of social entrepreneurship antecedents proposed by Jiao (2011) is empirically supported. To achieve this, semi-structured interviews were conducted with ten social entrepreneurs who have social enterprises located in Brazil. The results show that the five antecedents that make up the theoretical model proposed by Jiao (2011) are present in the intention of the social entrepreneurs to form a social enterprise. Nevertheless, the findings also showed the existence of a sixth antecedent, not described in the model proposed by Jiao. Based on this finding, a framework for analysis of antecedents that lead to the emergence of social enterprises is proposed, since besides the inclusion of a sixth antecedent, the framework has some distinctions with respect to the conceptual model (Jiao, 2011) on which this research is based.

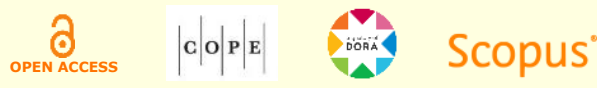


Specifically, in addition to the antecedents that lead to the emergence of social enterprises, this paper sought to analyze and discuss the definition of social entrepreneurship, as there are different and non-consensual definitions (Dacin, Dacin, \& Matear, 2010; Peredo \& McLean, 2006; Roy, Brumagim, \& Goll, 2014; Short, Moss, \& Lumpkin, 2009) both at the academy and in practice (Collavo, 2018). Therefore, the framework proposed also presents relations that help to minimize the theoretical misunderstanding about the social entrepreneurship definition, clarifying it. As a field that needs theoretical deepening (Austin, Stevenson, \& Wei-Skillern, 2006; Lanteri, 2015), this paper contributes to theoretical advancement in the social entrepreneurship field in two ways.

First, based on the extent of the antecedents, potential social entrepreneurs can understand the antecedents that led to the emergence of social enterprises, which may inspire the emergence of new social enterprises and a better comprehension of the aspects about this organization type. In addition, scholars of this field can broaden the basis concerning antecedents for conducting future empirical research in nascent social enterprises or entrepreneurs, which is a subfield of research that has recently been highlighted by researchers in the social entrepreneurship literature. Secondly, from the clarified definition of social entrepreneurship here proposed, it is possible for scholars to better understand the phenomena and the units of analysis they are investigating in this field. Additionally, practitioners can appropriate this definition to better understand the daily relationships that exist under social entrepreneurship.

\section{Theoretical Background}

Enterprises whose mission is essentially social are called social enterprises or social businesses (Barki, Comini, Cunliffe, Hart, \& Rai, 2015) and social innovation ventures when strictly related to the development of innovations for social problems solutions (Morais-da-Silva, Segatto, \& Bezerra-de-Sousa, 2019). Other nomenclatures used in the literature for this organization type are the terms inclusive business and social entrepreneurship (Collavo, 2018; Rosolen, Tiscoski, \& Comini, 2014). However, the use of the term social entrepreneurship in reference to a social enterprise can be understood as a misconception, because as Hjorth and Holt (2016, p. 50) affirm, "enterprise is not entrepreneurship". From this distinction, it is understood that enterprise concerns an organization, while social entrepreneurship alludes to a social phenomenon that has its own characteristics and, even though social enterprises are the actors that drive this phenomenon, social entrepreneurship cannot be reduced only to the actors, because there are processes and results that jointly shape the social entrepreneurship construct.

It should be stressed that social entrepreneurship generally refers to a process (Mair \& Martí, 2006). Thus, social entrepreneurship is achieved through the performance of a social enterprise, which in turn is idealized by a social entrepreneur (Ruskin, Seymour, \& Webster, 2016). Regarding the conceptualization of social entrepreneurship, this is still a recent theme and has

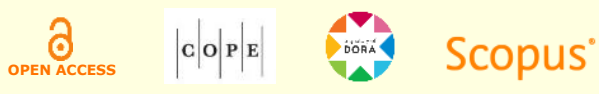


divergences in its conceptualization (Dwivedi \& Weerawardena, 2018). In general, social entrepreneurship refers to an innovative activity with a social aim (Austin et al., 2006), since the concept of social entrepreneurship encompasses the creation of social value that usually occurs by the introduction of innovations in services or products that have repercussions in the transformation of certain social realities (Ashraf et al., 2019; Rosolen, Tiscoski, \& Comini, 2014). About the scope of activities, social entrepreneurship "[...] encompasses a wide range of sectors, such as environmental protection, health care, education, and the reintegration of the long-term unemployed" (Hoogendoorn, 2016, p. 279).

Moving forward the discussion about social enterprises, these distance themselves from the performance of traditional enterprises (Shaw \& Carter, 2007; Zahra et al., 2009), since the main mission of the first type is social, unlike traditional organizations, which are exclusively economic. Historically, social business literature is based on three main views: (a) the one developed in Europe, whose tradition of social economy is based on associativism and cooperativism, focusing on actions of civil society organizations with public purposes; (b) the one developed in the United States of America, whose understanding is that of private sector organizations, traditional companies that seek to help solving social problems; and (c) the vision propagated mainly in developing countries, which seeks to minimize social problems such as poverty reduction and changing social conditions to include individuals who are on the margins of society through market initiatives (Fischer \& Comini, 2012). Based on this distinction and in view of the geographic positioning of this research's locus, the view adopted here for social enterprises consists of the third mentioned above.

Although social entrepreneurship is a field that requires its own theoretical development, some scholars argue that studies in this field may draw on prior research from the traditional entrepreneurship field (e.g., Haugh, 2012; Short et al., 2009). However, even if there are similarities between traditional and social entrepreneurship, these knowledge fields can be distinguished in divergent ways (Shaw \& Carter, 2007), because in some cases the purely economic mission of traditional entrepreneurship can raise research results that are not appropriate to the social mission of social entrepreneurship. In this way, it is necessary to consider the specificities of each field (Dacin et al., 2010) in conducting research. Thus, it is possible to affirm that most of the studies focus on the understanding of the entrepreneurial intentions that lead to the emergence of traditional enterprises, but there are few studies on this theme in social entrepreneurship (Liñán \& Fayolle, 2015).

Studies about the formation of traditional and/or social enterprises occur by the analysis of creation or discovery of opportunities (Alvarez \& Barney, 2007; González, Husted, \& Aigner, 2017), since opportunities are "situations in which new goods, services, raw materials, markets

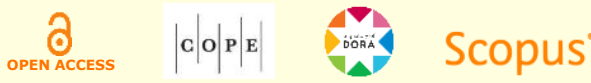


and organizing methods can be introduced through the formation of new means, ends, or meansends relationships" (Eckhardt \& Shane, 2003, p. 336). In social entrepreneurship, these opportunities are called social opportunities because they have certain characteristics that are not common to traditional entrepreneurship (González et al., 2017). In general, opportunities are essential for the development of new enterprises with a strictly social mission. However, before the analysis of the creation or the discovery of opportunities (Short et al., 2009) it is necessary to understand the antecedents that lead certain individuals to be entrepreneurs and to form a social enterprise, since antecedents lead to the emergence of social entrepreneurial actions that generate positive social impact (Jiao, 2011).

Regarding the antecedents, Shumate, Atouba, Cooper and Pilny (2014) argue that social entrepreneurs often create social enterprises based on a family legacy (e.g., when there are people in the entrepreneur's family who work on social causes) or in a transformation experience that occurs in adulthood (e.g., when the entrepreneur visits a developing country) that constitute a moral basis for conducting a social business. Going beyond this, other aspects are shown as relevant to the emergence of social enterprises, because according to Hockerts (2017), the experience of subjects with prior experiences with social problems characterizes an antecedent variable to impel the emergence of social enterprises. Understanding the prior life experiences of social enterprise founders helps to better realize the process of forming these enterprises (Christopolous \& Vogl, 2015; Germak \& Robinson, 2014). Such prior experiences with social problems are best appropriated through the entrepreneurial creativity of subjects (Ip et al., 2018). Considering creativity acts as a motivator of entrepreneurial intention (Fatoki, 2010), it helps identifying opportunities to be exploited through the formation of social enterprises.

Complementarily, social entrepreneurs in many cases demonstrate the importance of nonfinancial motives for engaging in this type of entrepreneurial action (Ruskin et al., 2016). As well as this, the social vision of certain entrepreneurs comes from certain values that they have, as subjective norms together with the interest for financial return stimulates the development of social innovation for the formation of social entrepreneurial attitude (Cavazos-Arroyo et al., 2017). In the same vein, there are individuals with certain social skills (e.g., collectivism and altruism) and economic skills (e.g., resources and professionalism) that together enable the creation of social enterprises, and the combinations of both types of skills can be considered antecedents (Chandra \& Shang, 2017).

Besides the issues discussed, it is possible to affirm that there are five antecedents responsible for the emergence of social entrepreneurship: "[...] desirability and feasibility of social entrepreneur in the decision-making process, human capital of social entrepreneur, social capital of social entrepreneur, social environment factors and institutional environment factors" (Jiao, 2011, p.

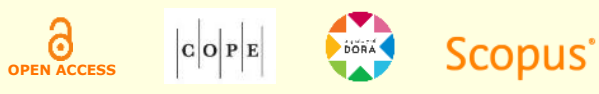


134). Based on these antecedents for the emergence of social entrepreneurship, the author developed a theoretical model that is presented in Figure 1.

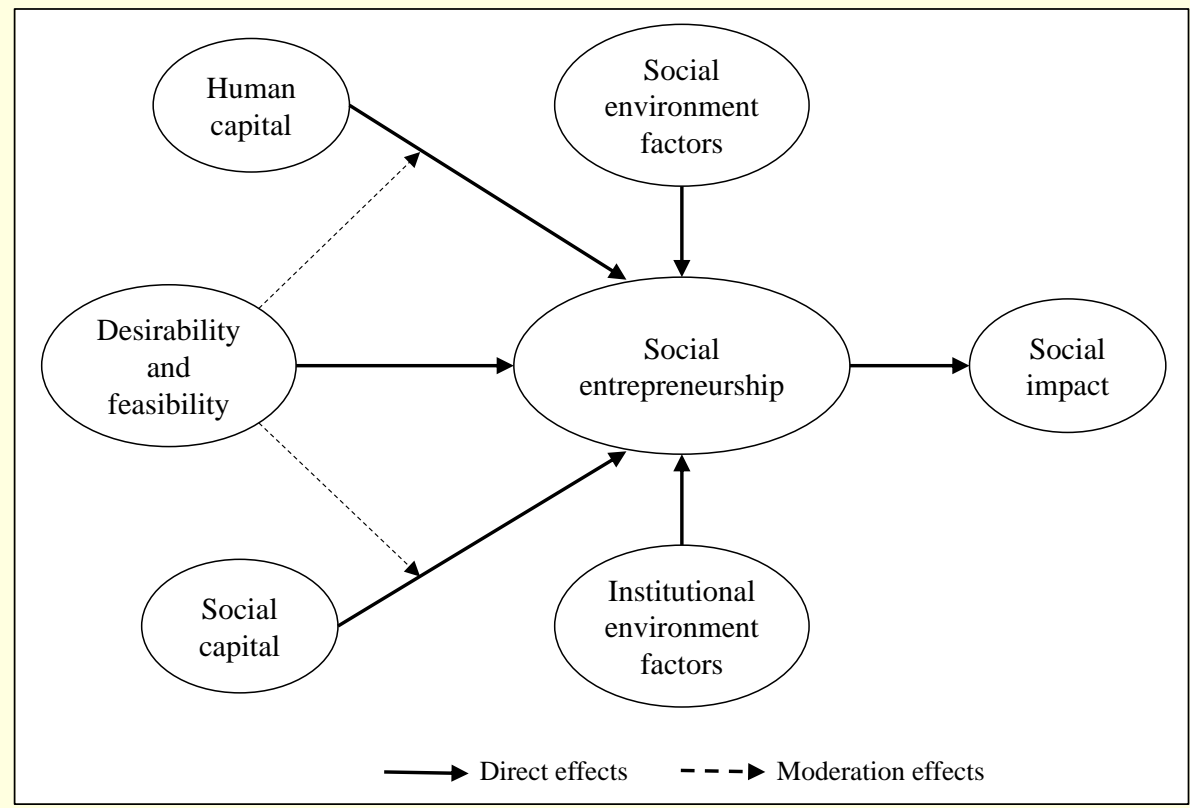

Figure 1. A research model for social entrepreneurship.

() Emerald Publishing. Reprinted with permission.

Source: Jiao, H. (2011). A conceptual model for social entrepreneurship directed toward social impact on society. Social Enterprise Journal, 7(2), 130-149. https://doi.org/10.1108/17508611111156600

Looking at the antecedents presented in Figure 1, the desirability and feasibility antecedent influences the motivation that drives the social entrepreneur towards the formation of a social enterprise (Thompson, Alvy, \& Lees, 2000). Thus, it is from the entrepreneurs' perceptions of desirability and feasibility that their entrepreneurial behavior can be understood, since both contribute to the formation of entrepreneurial intention (Foster \& Grichnik, 2013). Desirability is related to the desire to develop social activities, while feasibility is the subjective capacity of the social entrepreneur to start these activities through a social enterprise, and both are cognitive aspects (Jiao, 2011). Specifically, desirability can be considered as an individual lens focused on the attractiveness of the results, i.e., in the consequence of the entrepreneurial action (Scott $\&$ Twomey 1998), that could be the social and/or economic-characteristic focus of social enterprises. Feasibility is strictly related to the allocation of important resources (which may be financial, social, or human), i.e., it involves the individual's self-assessment of their ability to generate activities for the allocation of these resources within an enterprise (Foster \& Grichnik, 2013).

The human capital antecedent can be understood as the set of skills and knowledge that an individual has acquired or developed during his social life (Davidsson \& Honig, 2003), as well as the competence to integrate and use resources in the entrepreneurial process (Jiao, 2011). The very nature of social entrepreneurship induces the formation of different configurations of human capital, which may be influenced by contextual and institutional characteristics (Estrin, Mickiewicz, \& Stephan, 2016). The authors also state that the cognitive perspectives and

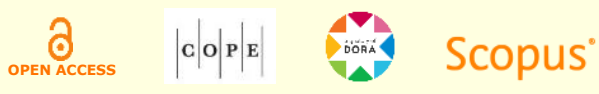


motivational aspects of social entrepreneurs' education also contribute to the formation of social enterprises.

The social capital antecedent is related to collective issues, where social capital is defined as the formation of networks that facilitate the cooperation among actors for growing mutual benefit (Putnam, 1993). Social capital takes shape through relationships or networks between societies, communities, and/or individuals, consisting of real or foreseeable knowledge-based assets (Nahapiet \& Ghoshal, 1998; Subramaniam \& Youndt, 2005). Thus, social capital can be understood as an instrument for the development of social and environmental actions, because this allows the formation of social networks, a known factor for the success of social enterprises activities (Jiao, 2011; Mair \& Martí, 2006).

The social environment factors consist of aspects such as support, funding, education to the formation of social entrepreneurial skills, and other regional aspects that can boost the formation of a social enterprise from the local reality (Jiao, 2011). In this way, the social and cultural context can influence the decision making of social entrepreneurs to create social enterprises, mainly through life experience of those with such social environment factors. The very existence of incubators or accelerators can influence this antecedent, since social entrepreneurs could have the desire but not the competence (e.g., business and management education) to create or structure social enterprises, seeking support in those agents.

Finally, the fifth antecedent (institutional environment factors) is related to institutional issues such as competitiveness within the industry, public policies created in the region, issues of legislation, and other occurrences in the system that may affect the formation of social enterprises (Jiao, 2011). Therefore, local support derived from market relations and government itself is relevant and may influence the formation or not of social enterprises. Specifically, if there are stimuli through public policies that support the emergence of social enterprises, for example, entrepreneurs may have a greater motivation to engage in such enterprises formation.

According to the model proposed by Jiao (2011), the five antecedents lead to the emergence of social entrepreneurship and the consequence of social entrepreneurship is the social impact creation. Still according to the proposed model, the desirability and feasibility antecedent of the social entrepreneur exerts a moderating effect on human capital and social capital antecedents in the formation of social entrepreneurship, as identified in Figure 1. Jiao (2011) further states that there may be other antecedents beyond these five, being necessary to conduct future research to validate or expand the proposed model. Thus, it is emphasized that this model is theoretical, and it is necessary to investigate whether there is support through the conduction of empirical research, which can generate the validation or the refutation of this model.

\section{Methodological Procedures}

In this section, the procedures adopted for the conduction of this research are presented, beginning with the research design, continuing with the data collection, and ending with the adopted plan for the data analysis.

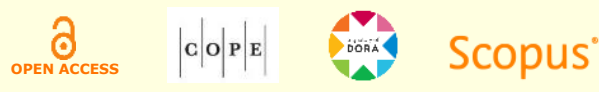




\section{Research design}

According to the aim, this research consists in a qualitative approach, since it focuses on the analysis of relations among antecedents that lead to the emergence of social enterprises. Within this approach, this research is classified as descriptive (Yin, 1981). Thus, it allows the description of the process that starts with the influence of antecedents on social entrepreneurs, promoting the formation of social enterprises and ending with social impact creation. The strategy used to conduct this research was the multi-case study (Creswell, 2014). The multi-case study adopted consists of a comparative analysis among the selected cases, focusing on the investigation of phenomena in the context of real life, contributing to the understanding of these phenomena, which may be individual, organizational, or social (Yin, 2002). Thus, the multi-case study in this research was composed of nine social enterprises located in Recife, northeast region of Brazil.

From this understanding, it is possible to delimit the research design adopted in this paper, which is presented in Figure 2. Each of the procedures that make up this design is described in the following topics.

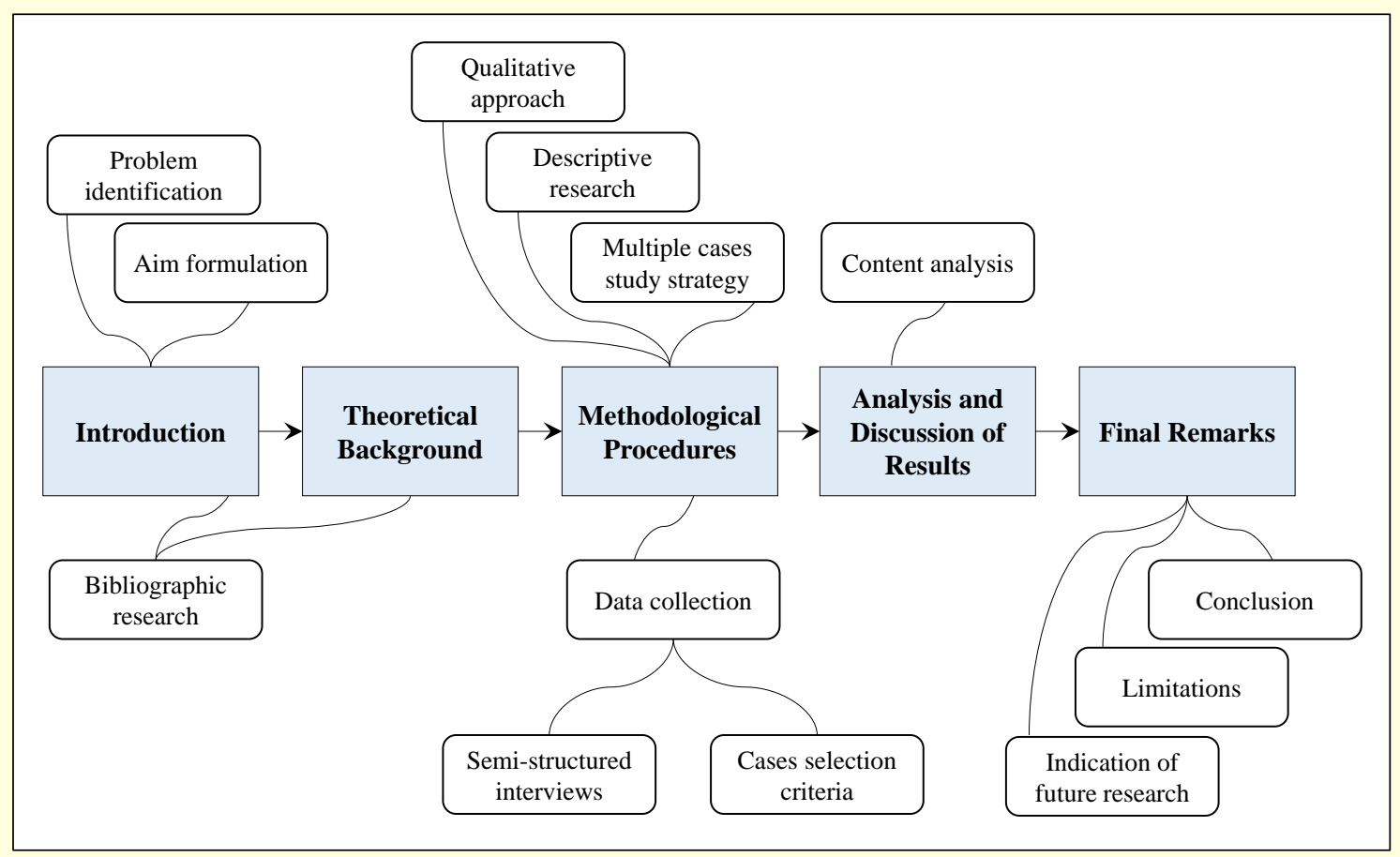

Figure 2. Research design

Source: Elaborated by the authors.

\section{Data collection}

To understand the antecedents that led to the emergence of social enterprises, the semi-structured interviews technique (Kvale \& Brinkmann, 2009) was used as a form of data collection. These interviews occurred with the social entrepreneurs who formed the nine social enterprises analyzed 
here. The semi-structured interviews were conducted individually and in a group with the entrepreneurs between September and December 2018. The interviews ranged from 42 minutes to one hour and 24 minutes in length. All the interviews took place face-to-face. During the interviews, a Free and Informed Consent Form was presented, exhibiting the research information. In this document, authorization was requested to expose the data gathered from the interviews and all the ten interviewees consented and authorized this. The interviews were recorded and later transcribed, totaling 148 pages of single-spaced text. The transcriptions occurred under the precepts of Nascimento and Steinbruch (2019), that is, the denaturalized transcription technique based on the reflexivity of the researchers was adopted as a way to better meet the thematic content analysis technique.

The snowball technique (Noy, 2008) was used to identify the cases and select the respondents. The first social entrepreneur was interviewed and, at the end of the interview, the contact of other social entrepreneurs was requested. Thus, at each new interview, there was the possibility of getting the contact of other social entrepreneurs to conduct new interviews. We stopped holding interviews when saturation (Mason, 2010) in the form of the phenomena was identified (Guest, Bunce, \& Johnson, 2006). This saturation was identified during the ninth interview. It is important to note that one of the interviews occurred with two entrepreneurs who were founders of the same social enterprise.

This paper is part of a broad piece of research that investigated the specific topics of strategy and social entrepreneurship in social enterprises. Thus, the interviews analyzed other themes besides the antecedents that lead to the emergence of social enterprises, with distinct blocks (with specific questions) for each theme in the same interview. The other themes analyzed in the scope of this broad research are broken down in other papers. Thus, it is noteworthy that more interviews were conducted, however, for the purposes of the paper presented here, only the first nine interviews were included, because the saturation for the topic addressed in this paper (antecedents of social enterprises) was identified in the ninth interview.

As far as the interview script goes, the block dedicated to the analysis of the social enterprises antecedents was at the beginning of the interviews, with the first question: How did the social enterprise come about? This question allowed the interviewees to deepen their narratives in the historical process of enterprise formation, with reports of challenges and social experiences. Then, the next question was: What social or environmental problems (e.g., poverty, lack of work, marginalization) did the enterprise seek to mitigate? From the historical understanding of the first question and the enterprise mission delimited in the second question, the third question was asked: What were the different situations experienced throughout your life and how did they boost your desire to create the enterprise?

Thus, the questions formed an iterative process, leading the respondents to enter deep and historical reflections, which allowed the researchers to understand what the life experiences were, and how they formed the antecedents that drove the emergence of the social enterprises. During each interview, specific unscheduled questions were elaborated to deepen the specific phenomena that emerged in each report. Even with the existence of distinct blocks for the

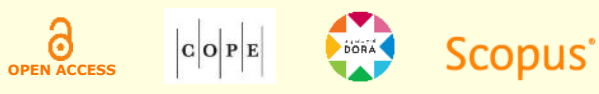


different themes covered by the broad research, it was identified that the narratives of one block could help understanding the phenomena of another block, which is why the interviews as a whole were analyzed for the theme of this paper.

As criteria for selecting cases, only enterprises that had a genuinely social mission were considered, which characterizes a social enterprise. Besides that, this study focused on the investigation of social enterprises present in Brazil, since there are several problems faced by different populations in this country, such as unemployment (Corrêa, Lima, \& Campos, 2015), poor education, high poverty rate, lack of water access (Sena et al., 2018), and lack of basic sanitation (Cavalcanti, Teixeira, \& Pontes, 2019) that have not yet been sufficiently healed. In addition, some regions within Brazil present more problems than others, such as the Northeast region, whose youths have lower levels of education compared to other regions (Neves, Gonçalves, \& Lima, 2015).

Within the Northeast, the city of Recife in the state of Pernambuco is listed in the ranking of the 50 most violent cities in the world (Consejo Ciudadano Para La Seguridad Pública Y La Justicia Penal A. C., 2018). Thus, the social enterprises located in Recife present a suitable basis for the analysis proposed in this paper, since they arise through various social problems and, in this way, can enrich the investigation on the antecedents that lead to the emergence of social enterprises.

Social enterprises constitute the objects of this research, while their founders are the subjects. Thus, the objects and the respective subjects are presented in Table 1, as well as the field of actuation of each enterprise and some information. Searching for the anonymity of the social entrepreneurs (founders) interviewed, identifications were adopted to refer to each of the interviewees during the Analysis and Discussion of Results section. These identifications are also presented in Table 1.

Table 1.

Identifications adopted to each founder interviewed and social enterprises information

\begin{tabular}{|c|c|c|c|}
\hline $\begin{array}{c}\text { Social } \\
\text { enterprise }\end{array}$ & Field & $\begin{array}{l}\text { Identifications } \\
\text { adopted and } \\
\text { interviewed } \\
\text { profile }\end{array}$ & Information \\
\hline 1 & Education & $\begin{array}{l}\text { Founder } \\
\text { interviewed (FI_1), } \\
\text { male, } 34 \text { years old, } \\
\text { journalist with MBA } \\
\text { in business } \\
\text { management }\end{array}$ & $\begin{array}{l}\text { This social enterprise started in } 2011 \text { and works } \\
\text { with basic, superior, and corporate education, } \\
\text { enabling the principles of social } \\
\text { entrepreneurship to be immersed in these } \\
\text { educational spheres and making a positive } \\
\text { impact. }\end{array}$ \\
\hline 2 & $\begin{array}{l}\text { Smart cities } \\
\text { / Habitation }\end{array}$ & $\begin{array}{c}\text { Founder } \\
\text { interviewed (FI_2), } \\
\text { male, } 30 \text { years old, } \\
\text { architect }\end{array}$ & $\begin{array}{l}\text { This social enterprise was formed in } 2017 \text { and } \\
\text { works to improve the housing of low-income } \\
\text { families in precarious conditions of life. The } \\
\text { enterprise's focus is on providing low cost } \\
\text { services such as architectural design for } \\
\text { community dwellers. }\end{array}$ \\
\hline
\end{tabular}

Continues

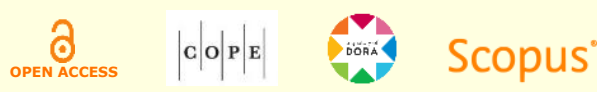


Table 1 (continued)

\begin{tabular}{|c|c|c|c|}
\hline 3 & $\begin{array}{l}\text { Social } \\
\text { inclusion }\end{array}$ & $\begin{array}{l}\text { Founder } \\
\text { interviewed (FI_3), } \\
\text { male, } 49 \text { years old, } \\
\text { technical course in } \\
\text { building }\end{array}$ & $\begin{array}{l}\text { This social enterprise started in } 2010 \text { and } \\
\text { contributes to the non-recurrence of people } \\
\text { leaving chemical recovery centers by teaching } \\
\text { them a new profession in the construction area. }\end{array}$ \\
\hline 4 & Environment & $\begin{array}{l}\text { Founder } \\
\text { interviewed (FI_4), } \\
\text { male, } 40 \text { years old, } \\
\text { high school } \\
\text { completed }\end{array}$ & $\begin{array}{l}\text { This enterprise was founded in } 2008 \text { and works } \\
\text { to raise awareness among residents in one } \\
\text { coastal region, enabling families to carry out } \\
\text { selective garbage collection. The enterprise's } \\
\text { members collect and transport the garbage } \\
\text { these families separate. }\end{array}$ \\
\hline 5 & $\begin{array}{l}\text { Social } \\
\text { inclusion }\end{array}$ & $\begin{array}{l}\text { Founder } \\
\text { interviewed (FI_5), } \\
\text { male, } 29 \text { years old, } \\
\text { journalist }\end{array}$ & $\begin{array}{l}\text { This enterprise started in } 2017 \text { and aims to give } \\
\text { greater visibility to the artists and cultural actions } \\
\text { that exist in the suburbs, which have no space in } \\
\text { the conventional media. A hot site was } \\
\text { constructed to show the cultural actions in } \\
\text { different communities. }\end{array}$ \\
\hline 6 & Environment & $\begin{array}{l}\text { Founder } \\
\text { interviewed (FI_6), } \\
\text { female, } 60 \text { years } \\
\text { old, technical } \\
\text { course in nursing } \\
\text { and in secretariat }\end{array}$ & $\begin{array}{l}\text { This enterprise started in 1984, developing } \\
\text { actions for the social causes of a community of } \\
\text { fishermen. Located in a fishing region, there is a } \\
\text { shortage of fish at times of the year and some } \\
\text { women decided to create the enterprise as a way } \\
\text { of teaching other women in the community to } \\
\text { make handicrafts and sell them. }\end{array}$ \\
\hline 7 & $\begin{array}{c}\text { Smart cities } \\
/ \\
\text { Environment }\end{array}$ & $\begin{array}{l}\text { Founder } \\
\text { interviewed (FI_7), } \\
\text { female, } 46 \text { years } \\
\text { old, bachelor's } \\
\text { degree in social } \\
\text { communication }\end{array}$ & $\begin{array}{l}\text { This social enterprise started in } 2016 \text { and the } \\
\text { main focus is on sustainable cooking, allowing } \\
\text { people in the communities to know how to enjoy } \\
\text { all parts of food and reuse food that would be } \\
\text { thrown away, generating household savings and } \\
\text { nutritional improvement. }\end{array}$ \\
\hline 8 & $\begin{array}{l}\text { Social } \\
\text { inclusion }\end{array}$ & $\begin{array}{l}\text { Founder } \\
\text { interviewed } 1 \\
\text { (FI_8.1), female, } \\
23 \text { years old, high } \\
\text { school completed, } \\
\text { and founder } \\
\text { interviewed } 2 \\
\text { (FI_8.2), male, } 34 \\
\text { years old, } \\
\text { bachelor's in law. }\end{array}$ & $\begin{array}{l}\text { This enterprise started in } 2015 \text { and works with } \\
\text { people living on the streets, delivering food and } \\
\text { drink to them weekly. In addition to this action, } \\
\text { the enterprise develops others to meet basic } \\
\text { needs for the same public, such as documents } \\
\text { emission or reissue, medical care, legal } \\
\text { assistance, dental care, and even aesthetic care. } \\
\text { The interview took place with (FI_8.1) and } \\
\text { (FI_8.2) that are two of the founders of this social } \\
\text { enterprise. }\end{array}$ \\
\hline 9 & Sports & $\begin{array}{l}\text { Founder } \\
\text { interviewed (FI_9), } \\
\text { male, } 34 \text { years old, } \\
\text { bachelor's degree } \\
\text { in administration } \\
\text { with a master's } \\
\text { degree in } \\
\text { international } \\
\text { development }\end{array}$ & $\begin{array}{l}\text { This enterprise works in the construction of } \\
\text { multisport courts in needy communities. The } \\
\text { construction of the court allows more than the } \\
\text { practice of sports, because the courts become } \\
\text { centers of coexistence for the members of the } \\
\text { community, being a venue for various cultural } \\
\text { events. This enterprise was started in } \\
\text { Guatemala in } 2006 \text {, but in } 2011 \text { it closed the } \\
\text { activities in that country and started again in } \\
\text { Brazil that same year. Currently, the enterprise } \\
\text { acts in different communities of eight countries, } \\
\text { but controls the operations from Recife. }\end{array}$ \\
\hline
\end{tabular}




\section{Data analysis plan}

The thematic content analysis technique was adopted (Bardin, 2009) in order to analyze the empirical data collected from the interviews. Thus, ex-ante analysis categories were adopted based on the model of Jiao (2011) and the theoretical background: (a) desirability and feasibility, (b) human capital, (c) social capital, (d) social environment factors; (e) institutional environment factors, (f) social enterprise, (g) social impact, and (h) social entrepreneurship. The first five categories of analysis correspond to the antecedents of social enterprises, and after the iterative analysis of the data, an ex-post category of analysis emerged, corresponding to another social enterprise antecedent not described in the theoretical background analyzed so far: (i) natural environment factors. All nine categories are analyzed together in the fourth section of this paper.

Notes were made during and after each interview, making it possible to compare some phenomena among cases. Triangulation was used as a form of validation and reliability of the data. This method consisted in the triangulation of data from the use of multiple sources of empirical evidence, because the diversity of subjects interviewed represents a triangulation of the evidence sources (Bruning, Godri, \& Takahashi, 2018). All the interviews were conducted and transcribed in Portuguese, but the reports from these interviews cited in this paper were freely translated into English.

\section{Analysis and Discussion of Results}

All business comes from an opportunity, and this is a reality also present in the context of social entrepreneurship, as identified in the interviewees' reports. The social enterprises analyzed here have diversity both in the focus of action and in the area and in the social impacts they generate, and the social opportunities (González et al., 2017) that drove the emergence of these enterprises vary due to this diversity. Thus, it was identified that the opportunities emerged from different situations (Hockerts, 2017), and in some cases, these opportunities were a consequence of environmental changes, corroborating the assertion that imperfections of the market or of the industry generate exogenous changes that are not controlled by entrepreneurs (Alvarez \& Barney, 2007). The following reports demonstrate how market changes can influence the generation of opportunities:

"Then, in that second moment, in this last crisis that occurred now in 2014/2015... Big companies that I already had a contract ... they had to cut their budgets for that kind of service. And then, some companies, three actually came to me to say, I wanted you to teach my team to do this, because I cannot pay your team to do this anymore. ... and then, it was when I began to discover that I could work in the educational area [...]" (FI_1).

"Okay, I worked with construction management and ... doing renovations and expansion of shopping malls. ... except that at the end of 2016 it was no longer making sense for me to stay in that place, because, so, it is far from Recife and the family, and the job was no longer pleasing. So, I did not have a purpose for that anymore and was at this point when the opportunity came, at the end of 2016 it was also the beginning of the crisis. So, one of the industries that gets affected from the beginning of an economic

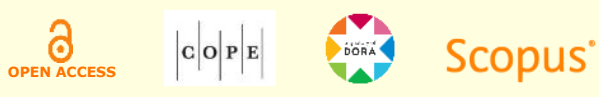


crisis is the civil construction. So, I decided to ask for vacations in that period ... just to try to see what I would do, I still had no idea" (FI_2).

The aforementioned reports highlight how the financial crisis experienced in Brazil since 2014 has generated economic changes in the commercial system, which for these entrepreneurs was the starting point to identify the opportunity they had to constitute a new business model based on their creativity (Ip et al., 2018). Although current discussions point out how the financial crisis can negatively affect enterprise's survival, the case of these entrepreneurs leads to a reflection on how the same fact capable of generating bankruptcy in some companies is also responsible for the identification of opportunities to the emergence of new enterprises.

Reinforcing the role of the financial crisis as an exogenous occurrence that impacts the social enterprise, it is relevant to emphasize one of the reports (FI_9) in which the social enterprise also went through a financial crisis in the initial stage of maturation, and because of this crisis encountered financial instability and had to migrate from Guatemala to Brazil, as identified in the following report. However, this crisis generated a situation that was positive for the social enterprise founder (FI_9), since it allowed the entrepreneur to understand errors that occurred in the enterprise management and the possibilities to improve and avoid problems in future.

\begin{abstract}
"So we were ready to change for a more robust business model, shall we say, financially, right? And what happens? We caught a financial crisis in 2008 from the United States that was the economic crisis. In 2011, we collected less than $10 \%$ of what we were collecting, and then many of the members left, and were acting only the co-founder of the social enterprise and me. Then we no more had that expected vision to expand in order to accelerate that social growth, and it did not happen. And the idea in that moment was let us try to go back to Brazil ...” (FI_9).
\end{abstract}

In addition to the stages of crisis, other situational issues experienced in the daily life of the subjects (Hockerts, 2017) may have raised attention to new opportunities for the emergence of social enterprises, as shown by the following reports:

"I worked as an individual, I have a small steel frame system installation company and in my need for manpower that does not have much in the market, I started receiving requests from friends who arrived and said they had a brother-in-law without work, needing a force, and asked if I did not have a vacancy" (FI_3).

"After a September 7 holiday in 2008, we saw that amount of residue that was found after that holiday in the beach was big and the city hall had some deficiency in giving the correct destination" (FI_4).

"How did we start our work? The wives of the fishermen and the women who caught shellfish to sell came to me to organize and set up an entity. And this club served to empower the mothers, because there is a time here in the year that the fishermen spend six months without being able to fish and the mothers had no other... other income to feed their children" (FI_6).

"This came from an idea from within the church, from a young church group. Not that it was the young group, but people who participated in the group, who knew each other from the neighborhood, especially from our coordinator. He was the idealizer and began looking for people who wanted to think of something more aimed at social, a social project. So we got together and started doing a simple even food distribution job on Wednesdays that is our first project and the biggest one. It was from being on the street that we started thinking about bigger things" (FI_8.2).

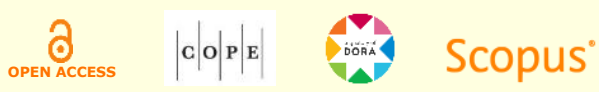


From the above reports, opportunities are related to the specificity of each situation experienced by the subjects, and in some cases, it is possible to corroborate the assertion that situations experienced in adulthood may be antecedents for the emergence of a social enterprise (Shumate et al., 2014). In the first cited report (FI_3), because of his work with a little-known technique that was not widely used in Brazil, the subject had difficulty finding specialized professionals to perform the work. There was an opportunity to train and qualify friends to work with the constructive technique of steel frame, which later allowed the entrepreneur to enter the social field itself. In this case, the industry required a specialized workforce in the steel frame technique, since this form of work was not typical of Brazil, and for its accomplishment, a process of training and learning of workers from other areas was required so that the entrepreneur could sustain the business.

In the second report (FI_4), the subject's experience in a particular coastal region and a realization that the holidays increased the index of people on the beaches and, consequently, the accumulation of garbage on these beaches, generated the inquisitiveness of the subject that made him decide together with friends to generate an action to minimize the environmental negative impacts caused to that ecosystem. This case demonstrates how the social and/or environmental values that a person possesses can induce the emergence of social enterprises (Cavazos-Arroyo et al., 2017).

In the third report (FI_6), we see that the natural characteristic of a fishing region means that in some epochs there is a shortage of fish and crustaceans. This directly affects the ability of the people that depend on fishing as a means to make a living. The solution found at that time by the women of the fishermen families was to invest in parallel sells. These two cases are contrasting, since the first one arose from the pollution generated by the human action, whereas this last one is cyclical, coming from environmental conditions that are natural.

In the fourth already cited report (FI_8.2), social interaction in a religious environment induced the need for intensification of action to generate social action, and maybe something strictly related to the need to go beyond what exists in society. This goes beyond the individual and seeks a way to help others in a collective action. The interesting thing about this case is that from the initial action new ideas emerged, i.e., they identified new opportunities to go beyond the simple action of feeding people in a street situation, even generating actions that can rescue them from this situation.

Another report (FI_5) analyzed here clearly demonstrates how the social values of people can induce the emergence of social enterprises (Cavazos-Arroyo et al., 2017), since the social entrepreneur worked in a traditional media enterprise and realized that there is a lack of space in traditional media for artists and events that occur in underprivileged communities.

Another intriguing case about opportunities is that of social enterprise 7, which began with handicraft workshops for people in a poor community. During these meetings, the respondent (FI_7) identified that people who participated were hungry and began to offer snacks during the

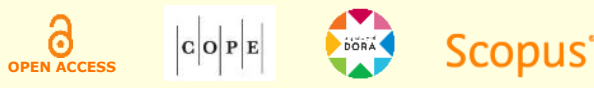


workshops. However, these snacks were made with the reuse of leftovers and all parts of food, since it was common practice in the social entrepreneur daily life never to waste food and always reuse. In addition, the workshop participants praised the food, many did not believe it when the interviewee spoke about what they were made of, and from these findings, the social entrepreneur identified that these people could be taught to practice sustainable cooking in their homes and/or for commercialization. This is an example of an antecedent based on non-financial motivations that leads to the emergence of a social enterprise (Ruskin et al., 2016).

However, during the report this entrepreneur explained that this practice of reusing food comes from childhood, because the entrepreneur's family was poor and the mother collected food that could not be sold at fairs to feed the family members. From this necessity, the total utilization of the food that would be thrown away by traders at fairs was practiced. This report demonstrates how life experience (Hockerts, 2017; Ip et al., 2017) based on a situation of poverty served as inspiration for the interviewee to become more aware about the reuse of food in daily life. This stage arose from an opportunity identified by the entrepreneur's mother to feed the family and today is reflected in an opportunity that supported the realization of sustainable cooking in the life of the interviewee.

In another stage of this social enterprise, during the realization of handicraft workshops, the interviewee (FI_7) identified that the sustainable cooking that was already practiced in daily life could help other people who also lived in needy communities, identifying other opportunities, which have become the main activity of this social enterprise. From this report, it is possible to refute the assertion of Shumate et al. (2014) that only the transformative situations experienced in adulthood lead to the emergence of social enterprises. In this case, the transformative experience occurred in the respondent's childhood, and thus it is possible to affirm that the transformative experiences that lead to the emergence of social enterprises occur in both adulthood and childhood.

The story that supports the emergence of social enterprise 7 is a typical example of the principle that supports the emergence of social enterprises. Because when the subject experiences a situation of poverty and/or injustice, marginalization, unemployment, among others, a feeling is generated that drives the subject to help other people who are going through that situation by means of forming a social enterprise (Hockerts, 2017). Going beyond this, from the analysis it is possible to affirm that all the cases presented here have some antecedents that led to the emergence of social enterprises. These include the desirability and feasibility of the social entrepreneur in the decision-making process, the social capital and the human capital of social entrepreneurs, institutional environment factors, and social environment factors (Jiao, 2011).

For example, the crisis scenarios that have driven some entrepreneurs (FI_1; FI_3; FI_9) to set up and/or reformulate the social enterprise can be understood as factors of the institutional environment. The desirability and feasibility of the social entrepreneur in the decision-making process are comprehensible in all reports (FI_1; FI_2; FI_3; FI_4; FI_5; FI_6; FI_7; FI_8.1; FI_8.2 and FI_9), while the life story that underlies the emergence of the business, as in the case of social enterprise 7, is related to the social capital of the social entrepreneur. On the other hand, human

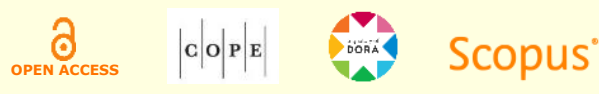


capital becomes essential in the cases of social enterprise 9 and social enterprise 8 . Moreover, the situation of garbage left on the beaches in the case of social enterprise 4, the social exclusion of people living in streets in the case of social enterprise 8 , and the fishermen who seasonally lack income in the case of social enterprise 6 can be listed as social environment factors.

However, in the latter case, as reported (FI_6), it is understood that there is a fine line between social and environment factors, since the social environment factors are derived from the factors of the natural environment of that ecosystem. Thus, through the case presented here, it is possible to understand that the antecedents that lead to the emergence of social enterprises are not limited to those exposed by Jiao (2011), being possible to consider, as a complement, the natural environment factors, as presents the framework graphically depicted in Figure 3.

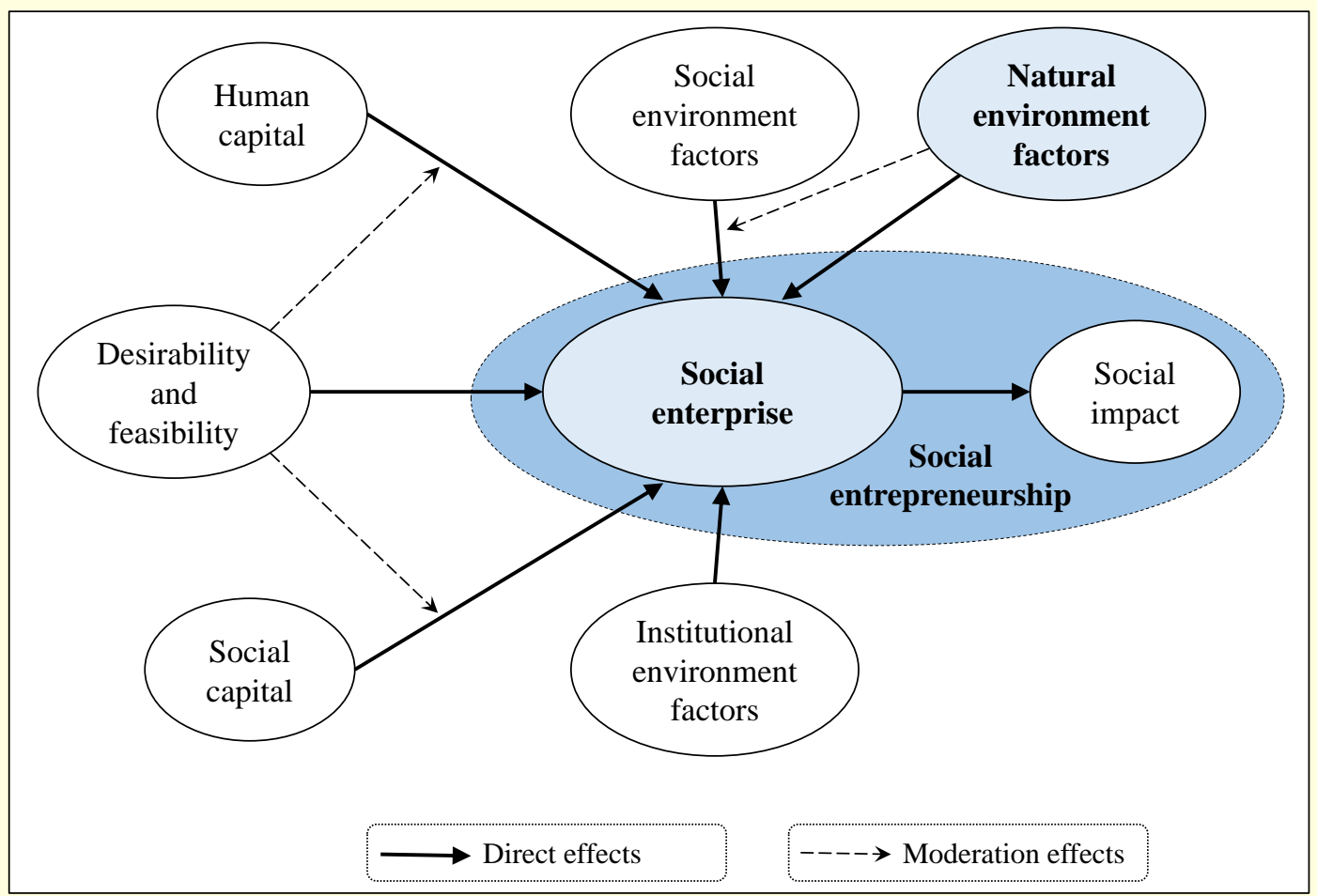

Figure 3. Framework for analysis of antecedents that lead to the emergence of social enterprises Source: Elaborated by the authors based on the empirical evidence and on Jiao, H. (2011). A conceptual model for social entrepreneurship directed toward social impact on society. Social Enterprise Journal, 7(2), 130-149. https://doi.org/10.1108/17508611111156600

In the framework are presented the five antecedents and the creation of social impact that are defended by Jiao (2011). Based on the empirical evidence from one of the cases (FI_6), the inclusion of a sixth antecedent (natural environment factors) is proposed, as well as other modifications from all cases (represented in blue) to the conceptual model of Jiao (2011). Therefore, through the empirical evidence it is possible to affirm that this sixth antecedent generates an influence or a moderate effect in the fourth antecedent (social environment factors) proposed by Jiao (2011), as represented in the framework proposed here - Figure 3. 
Moreover, the conceptual model proposed by Jiao (2011) presents a relationship that does not match the analysis identified in this empirical research, since the model of this author demonstrates that the antecedents generate social entrepreneurship and this generates social impact. Based on the analysis developed here, it is identified that the antecedents lead to the emergence of social enterprises and not of social entrepreneurship as defended by Jiao (2011). This author also affirms in his conceptual model that social entrepreneurship has as a consequence the generation of social impact. However, according to the analysis carried out, it is identified that social enterprises generate social impact and not social entrepreneurship as advocated by Jiao (2011).

Thus, in the framework proposed in Figure 3 is argued that antecedents lead to the emergence of social enterprise and the consequence of this is the creation of social impact. From this perspective, it is possible to affirm that the actions developed by a social enterprise together with the social impact provided by this organization constitute the social entrepreneurship. This understanding of social entrepreneurship needs to be clarified so that there is no theoreticalempirical confusion in this field, since enterprise is not entrepreneurship and vice versa (Hjorth \& Holt, 2016).

\section{Final Remarks}

From the reports of Brazilian social entrepreneurs analyzed here, it has been identified that the conceptual model proposed by Jiao (2011) is empirically supported, but with some modifications. The first modification is in the inclusion of a sixth antecedent (natural environment factors) not described by Jiao (2011). This sixth antecedent emerged from the natural characteristics of an ecosystem present in a community of fishermen, demonstrating how local and nature characteristics can influence the living conditions of certain communities and thus can foster the emergence of social enterprises. From this, the assumption is raised that entrepreneurs must have the expertise and absorptive capacity (on an individual level) to assimilate knowledge and resources from both local nature and the market, identifying the potential value of them and exploiting them through the formation of social enterprises. Thus, it can be assumed that absorptive capacity, the ability to recognize the value of a novelty, assimilating it and applying it commercially (Cohen \& Levinthal, 1990), may be directly related to the antecedents of social enterprises. This can be deepened in future research, as absorptive capacity was not part of this paper.

The second modification proposed to the model of Jiao (2011) emerges from this conceptual model's representation that antecedents generate social entrepreneurship and this creates social impact. In this modification, it is identified that antecedents lead to the emergence of social enterprises and not of the social entrepreneurship. In addition, it is the social enterprises that create social impact and not social entrepreneurship. Thus, it is perceived that social entrepreneurship is composed through social enterprise actions jointly with the social impact generated by this organization. These changes, identified through analysis of the reports, sustain the development of a framework for analysis of antecedents that leads to the emergence of social enterprises, which was elaborated based on the conceptual model proposed by Jiao (2011).

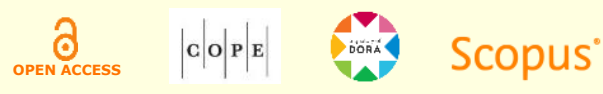


From the framework proposed in this paper, researchers of the social entrepreneurship field can deepen research on aspects that lead to the emergence of social enterprises. Moreover, the framework assists in the theoretical advance of the definition of social entrepreneurship, highlighting the relationship between social enterprise activities and social impact creation as a set that constitutes social entrepreneurship. This conceptual clarification contributes to minimize mistakes that may exist in both theoretical and empirical studies, since an inadequate conceptualization can cause deviations during data collection or data analysis, allowing the generation of potential erroneous results. This paper also contributes to the explanation of situations and distinct social problems experienced by social entrepreneurs, allowing individuals who want to generate a social enterprise to better understand the initial formation process of this organization type. Moreover, understanding the antecedents to the formation of social enterprises presented here may help in the creation of educational programs dedicated to the training of social entrepreneurs (Germak \& Robinson, 2014) in social incubators and accelerators.

This paper presents some limitations. Firstly, the analysis of cases coming from a single Brazilian region, because the country presents other regions with various social problems and, consequently, other social enterprises that could broaden the discussion. Secondly, as the focus was on the antecedents experienced by social entrepreneurs, there was no possibility of collecting other data sources to analyze these phenomena, such as documents or observations, which prevented triangulation of data collection techniques. According to the scope of this research, it was not possible to interview other members of the social enterprises analyzed here, because only the social entrepreneurs (founders) could shed light on the previous phenomena to the formation of the social enterprises, which made it impossible to form a more robust research corpus.

As much as the findings of this research are relevant to the field of social entrepreneurship, there are still gaps that need to be filled for the theoretical advancement of this field. Attempting to contribute to this theoretical deepening, directions for future research are proposed in Table 2 . The proposals contained in this research agenda are comprehensive, involving different levels of analysis and agents that are interconnected in the social entrepreneurship constitution. For each study proposal, possible research methods are indicated that can be followed. Hence, it is possible that these directions assist in the discovery of phenomena that can advance not only the theoretical understanding but also the practical one, about the conjuncture that permeates social entrepreneurship.

Table 2

Future research agenda

\begin{tabular}{|c|c|}
\hline Content (What) & Method (How) \\
\hline $\begin{array}{l}\text { Investigate the antecedents in regions whose nature ecosystems are } \\
\text { diversified, which may deepen the knowledge about the natural environment } \\
\text { factors antecedent discovered herein. }\end{array}$ & $\begin{array}{l}\text { Qualitative approach, such as } \\
\text { ethnography and life story. }\end{array}$ \\
\hline & Continues \\
\hline$\partial_{\text {OPEN ACCESS }} \quad|\mathbf{c}| \mathbf{o}|\mathbf{P}| \mathbf{E} \mid$ & $\begin{array}{l}\text { BAR } \\
\substack{\text { Brazilian } \\
\text { Administration } \\
\text { Review }}\end{array}$ \\
\hline
\end{tabular}


Table 2 (continued)

Understand interactional phenomena among the natural environment factors and the other antecedents that lead to the emergence of social enterprises.

Concerning the scope of social enterprise actions, they can be compensatory (arise in order to compensate for the local failures of the capitalist system, such as marginalization and unemployment) or transformative (arise in order to change the global hegemonic system through transnational actions) (Newey, 2018). Thus, future studies may specifically analyze whether or not the antecedents that lead to the emergence of compensatory social enterprises are the same as those of transformative social enterprises, since such classification was not adopted in this paper.

Analyze whether a compensatory social enterprise can migrate towards a transformative one, trying to identify and to understand which antecedents are responsible for this change of local action to an international one, since the entrepreneur may not have experienced the local social problems of other countries.

Would the antecedents be the same in the three main views on social enterprises? This investigation is intriguing because as the formation logic of these social businesses is different, it is necessary to analyze whether the antecedents can also be.

Analyze the framework proposed here in social enterprises that operate in other regions of Brazil, as well as in other countries, allowing a cross-cultural analysis of the antecedents that lead to the emergence of social enterprises.

Develop scales to measure each of the antecedents, which can enable greater appropriation of these constructs through quantitative analysis.

Validate the proposed framework using large samples.

Replication of this research may lead to the discovery of other antecedents, being possible to complement the framework proposed in this paper.

Analyze the innovation capabilities of social enterprises, investigating whether and how they differ or not from those found in traditional enterprises. The innovation performance of companies is driven by the innovation capabilities, which are: technological development capability, operations capability, management capability, and transaction capability (Zawislak, Alves, Tello-Gamarra, Barbieux, \& Reichert, 2012). As much as these capabilities are widely discussed in traditional entrepreneurship, the specific context of social enterprises requires a deeper understanding of how these capabilities are related to social and economic issues, especially on social innovation.

Analyze whether and how the strategic foresight techniques that are widely adopted in traditional entrepreneurship can be adopted by social enterprises. As innovation requires constant change, strategic foresight is a way of predicting weak signals and technological trends that can change the future, allowing for prior adaptation to these changes - innovations development. As the social and economic context of social enterprises tends to be complex, strategic foresight can be an innovative action so that these enterprises propagate the social impact.

Investigate whether and how social enterprises can boost the development of public policies and, in contrast, how these policies at the local, regional, or national level can boost the social impact of these enterprises.

Understand social entrepreneurship as a complex process composed of different agents (entrepreneurs, enterprises, citizens, communities, government, etc.) in various social and economic interactions.
Qualitative approach, such as phenomenology.

Qualitative approach, such as multi-case studies.

Qualitative approach, such as ethnomethodology and grounded theory.

Qualitative approach, such as comparative multi-case studies among USA, Europe, and developing countries.

Qualitative approach, such as multi-case studies.

Quantitative approach, such as fuzzy logic.

Quantitative approach, such as multivariate linear regression.

A variety of qualitative, quantitative, and mixed approaches can be adopted.

Qualitative approach, such as multi-case studies.

Qualitative approach, such as multi-case studies.

Qualitative approach, such as grounded theory.

Qualitative and quantitative approaches, such as social network analysis. 


\section{Acknowledgments}

The authors acknowledge funding from the Coordination for the Improvement of Higher Education Personnel (Coordenação de Aperfeiçoamento de Pessoal de Nivel Superior - CAPES).

\section{References}

Ashraf, M. M., Razzaque, M. A., Liaw, S.-T., Ray, P. K., \& Hasan, M. R. (2019). Social business as an entrepreneurship model in emerging economy: Systematic review and case study. Management Decision, 57(5), 1145-1161. https://doi.org/10.1108/MD-04-2017-0343

Alvarez, S. A., \& Barney, J. B. (2007). Discovery and creation: Alternative theories of entrepreneurial action. Strategic Entrepreneurship Journal, 1(1-2), 11-26. https://doi.org/10.1002/sej.4

Austin, J., Stevenson, H., \& Wei-Skillern, J. (2006). Social and commercial entrepreneurship: Same, different, or both?. Entrepreneurship Theory and Practice, 30(1), 1-22. https://doi.org/10.1111/j.1540-6520.2006.00107.x

Baierl, R., Grichnik, D., Spörrle, M., \& Welpe, I. M. (2014). Antecedents of social entrepreneurial intentions: The role of an individual's general social appraisal. Journal of Social Entrepreneurship, 5(2), 123-145. https://doi.org/10.1080/19420676.2013.871324

Bardin, L. (2009). Análise de conteúdo [Content analysis] (4th ed.). Lisboa, Portugal: Edições 70.

Barki, E., Comini, G., Cunliffe, A., Hart, S., \& Rai, S. (2015). Social entrepreneurship and social business: Retrospective and prospective research. RAE - Revista de Administração de Empresas, 55(4), 380-384. http://dx.doi.org/10.1590/S0034-759020150402

Battilana, J., Sengul, M., Pache, A.-C., \& Model, J. (2014). Harnessing productive tensions in hybrid organizations: The case of work integration social enterprises. Academy of Management Journal, 58(6), 1658-1685. https://doi.org/10.5465/amj.2013.0903

Bruning, C., Godri, L., \& Takahashi, A. R. W. (2018). Triangulação em estudos de caso: Incidência, apropriações e mal-entendidos em pesquisas da área de Administração. Administração: Ensino e Pesquisa, 19(2), 277-307. https://doi.org/10.13058/raep.2018.v19n2.889

Cavalcanti, A., Teixeira, A., \& Pontes, K. (2019). Regression model to evaluate the impact of basic sanitation services in households and schools on child mortality in the municipalities of the state of Alagoas, Brazil. Sustainability, 11(15), 4150. https://doi.org/10.3390/su11154150

Cavazos-Arroyo, J., Puente-Diaz, R., \& Agarwal, N. (2017). An examination of certain antecedents of social entrepreneurial intentions among Mexico residents. Revista Brasileira de Gestão de Negócios, 19(64), 180-199. http://dx.doi.org/10.7819/rbgn.v19i64.3129

Chandra, Y., \& Shang, L. (2017). Unpacking the biographical antecedents of the emergence of social enterprises: A narrative perspective. Voluntas, 28, 2498-2529. https://doi.org/10.1007/s11266-017-9860-2

Chell, E., Nicolopoulou, K., \& Karataş-Özkan, M. (2010). Social entrepreneurship and enterprise: International and innovation perspectives. Entrepreneurship $\mathcal{F}$ Regional Development, 22(6), 485-493. https://doi.org/10.1080/08985626.2010.488396

Christopoulos, D., \& Vogl, S. (2015). The motivation of social entrepreneurs: The roles, agendas and relations of altruistic economic actors. Journal of Social Entrepreneurship, 6(1), 1-30. https://doi.org/10.1080/19420676.2014.954254

Cohen, W. L., \& Levinthal, D. A. (1990). Absorptive Capacity: A New Perspective on Learning and Innovation. Administrative Science Quarterly, 35(1), 128-152. https://doi.org/10.2307/2393553

Collavo, T. (2018). Unpacking social entrepreneurship: Exploring the definition chaos and its consequences in England. Journal of Entrepreneurship, Management and Innovation, 14(2), 49-82. https://doi.org/10.7341/20181423 
Consejo Ciudadano Para La Seguridad Pública Y La Justicia Penal A. C. (2018, March). Metodología del ranking (2017) de las 50 ciudades más violentas del mundo. Retrieved from http://www.seguridadjusticiaypaz.org.mx/biblioteca/download/6-prensa/242-las-50-ciudades-mas-violentasdel-mundo-2017-metodologia.

Corrêa, L. F. C., Lima, J. P. R., \& Campos, L. H. R. (2015). Uma análise da pobreza multidimensional do Nordeste metropolitano com uso de modelo de equações estruturais. Revista Brasileira de Estudos de População, 32(2), 313-333. http://dx.doi.org/10.1590/S0102-30982015000000018

Creswell, J. W. (2014). Research design: Qualitative, quantitative, and mixed methods approaches (4th ed.). London: Sage Publications.

Dacin, P. A., Dacin, M. T., \& Matear, M. (2010). Social entrepreneurship: Why we don't need a new theory and how we move forward from here. Academy of Management Perspectives, 24(3), 37-57. https://doi.org/10.5465/amp.24.3.37

Davidsson, P., \& Honig, B. (2003). The role of social and human capital among nascent entrepreneurs. Journal of Business Venturing, 18(3), 301-331. https://doi.org/10.1016/S0883-9026(02)00097-6

Dwivedi, A., \& Weerawardena, J. (2018). Conceptualizing and operationalizing the social entrepreneurship construct. Journal of Business Research, 86, 32-40. https://doi.org/10.1016/j.jbusres.2018.01.053

Eckhardt, J. T., \& Shane, S. A. (2003). Opportunities and entrepreneurship. Journal of Management, 29(3), 333-349. https://doi.org/10.1016/S0149-2063(02)00225-8

Estrin, S., Mickiewicz, T., \& Stephan, U. (216). Human capital in social and commercial entrepreneurship. Journal of Business Venturing, 31(4), 449-467. https://doi.org/10.1016/j.jbusvent.2016.05.003

Fatoki, O. O. (2010). Graduate entrepreneurial intention in South Africa: Motivations and obstacles. International Journal of Business and Management, 5(9), 87-98. https://doi.org/10.5539/ijbm.v5n9p87

Fischer, R. M., \& Comini, G. (2012). Sustainable development: From responsibility to entrepreneurship. Revista de Administração, 47(3), 363-369. http://dx.doi.org/10.1590/S0080-21072012000300002

Foster, F., \& Grichnik, D. (2013). Social entrepreneurial intention formation of corporate volunteers. Journal of Social Entrepreneurship, 4(2), 153-181. https://doi.org/10.1080/19420676.2013.777358

Germak, A. J., \& Robinson, J. A. (2014). Exploring the motivation of nascent social entrepreneurs. Journal of Social Entrepreneurship, 5(1), 5-21. https://doi.org/10.1080/19420676.2013.820781

González, M. F., Husted, B. W., \& Aigner, D. J. (2017). Opportunity discovery and creation in social entrepreneurship: An exploratory study in Mexico. Journal of Business Research, 81, 212-220. https://doi.org/10.1016/j.jbusres.2016.10.032

Guest, G., Bunce, A., \& Johnson, L. (2006). How many interviews are enough?: An experiment with data saturation and variability. Field Methods, 18(1), 59-82. https://doi.org/10.1177/1525822X05279903

Haugh, H. (2012). The importance of theory in social enterprise research. Social Enterprise Journal, 8(1), 7-15. https://doi.org/10.1108/17508611211226557

Hjorth, D., \& Holt, R. (2016). It's entrepreneurship, not enterprise: Ai Weiwei as entrepreneur. Journal of Business Venturing Insights, 5, 50-54. https://doi.org/10.1016/j.jbvi.2016.03.001

Hockerts, K. (2017). Determinants of social entrepreneurial intentions. Entrepreneurship Theory and Practice, 41(1), 105-130. https://doi.org/10.1111/etap.12171

Hoogendoorn, B. (2016). The prevalence and determinants of social entrepreneurship at the macro level. Journal of Small Business Management, 54(s1), 278-296. https://doi.org/10.1111/jsbm.12301

Ip, C. Y., Liang, C., Wu, S.-C., Law, K. M. Y., \& Liu, H.-C. (2018). Enhancing social entrepreneurial intentions through entrepreneurial creativity: A comparative study between Taiwan and Hong Kong. Creativity Research Journal, 30(2), 132-142. https://doi.org/10.1080/10400419.2018.1446744

Ip, C. Y., Wu, S.-C., Liu, H.-C. \& Liang, C. (2017). Revisiting the antecedents of social entrepreneurial intentions in Hong Kong. International Journal of Educational Psychology, 6(3), 301-323. http://dx.doi.org/10.17583/ijep.2017.2835

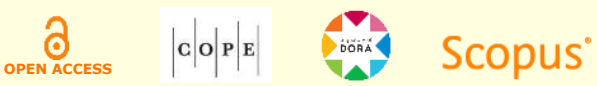


Jiao, H. (2011). A conceptual model for social entrepreneurship directed toward social impact on society. Social Enterprise Journal, 7(2), 130-149. https://doi.org/10.1108/17508611111156600

Kvale, S., \& Brinkmann, S. (2009). Interviews: Learning the craft of qualitative research interviewing (2nd ed.). London, UK: Sage Publications

Lanteri, A. (2015). The creation of social enterprises: Some lessons from Lebanon. Journal of Social Entrepreneurship, 6(1), 42-69. https://doi.org/10.1080/19420676.2014.954256

Liñán, F., \& Fayolle, A. (2015). A systematic literature review on entrepreneurial intentions: Citation, thematic analyses, and research agenda. International Entrepreneurship and Management Journal, 11, 907-933. https://doi.org/10.1007/s11365-015-0356-5

Mair, J., \& Martí, I. (2006). Social entrepreneurship research: A source of explanation, prediction, and delight. Journal of World Business, 41(1), 36-44. https://doi.org/10.1016/j.jwb.2005.09.002

Mason, M. (2010). Sample size and saturation in $\mathrm{PhD}$ studies using qualitative interviews. Forum: Qualitative Social Research, 11(3), Art. 8. http://dx.doi.org/10.17169/fqs-11.3.1428

Morais-da-Silva, R. L., Segatto, A. P., \& Bezerra-de-Sousa, I. G. (2019). Connecting two sides: A qualitative study on social innovation ventures and poor communities in an emerging economy. Voluntas. https://doi.org/10.1007/s11266-019-00156-x

Nahapiet, J., \& Ghoshal, S. (1998). Social capital, intellectual capital, and the organizational advantage. Academy of Management Review, 23(2), 242-266. https://doi.org/10.5465/amr.1998.533225

Nascimento, L. S., \& Steinbruch, F. K. (2019). "The interviews were transcribed”, but how? Reflections on management research. RAUSP Management Journal, 54(4), 413-429. https://doi.org/10.1108/RAUSP-052019-0092

Neves, M. C. R., Gonçalves, M. F., \& Lima, J. E. (2015). Mundos distintos e realidades semelhantes: Empregabilidade dos jovens no Nordeste e Sudeste brasileiros. Revista Brasileira de Estudos de População, 32(2), 335-356. http://dx.doi.org/10.1590/S0102-30982015000000019

Newey, L. R. (2018). ‘Changing the system’: Compensatory versus transformative social entrepreneurship. Journal of Social Entrepreneurship, 9(1), 13-30. https://doi.org/10.1080/19420676.2017.1408671

Noy, C. (2008). Sampling knowledge: The hermeneutics of snowball sampling in qualitative research. International Journal of Social Research Methodology, 11(4), 327-344. https://doi.org/10.1080/13645570701401305

Peredo, A. M., \& McLean, M. (2006). Social entrepreneurship: A critical review of the concept. Journal of World Business, 41(1), 56-65. https://doi.org/10.1016/j.jwb.2005.10.007

Putnam, R. D. (1993). The prosperous community: Social capital and public life. The American Prospect, (13), 35-42. Retrieved from: https://prospect.org/article/prosperous-community-social-capital-and-public-life

Rosolen, T., Tiscoski, G. P., \& Comini, G. M. (2014). Empreendedorismo social e negócios sociais: Um estudo bibliométrico da publicação nacional e internacional. Revista Interdisciplinar de Gestão Social, 3(1), 85-105. http://dx.doi.org/10.9771/23172428rigs.v3i1.8994

Roy, A., Brumagim, A., \& Goll, I. (2014). Predictors of social entrepreneurship success: A cross-national analysis of antecedent factors. Journal of Social Entrepreneurship, 52-59. http://dx.doi.org/10.1080/19420676.2013.820783

Ruskin, J., Seymour, R. G., \& Webster, C. M. (2016). Why create value for others? An exploration of social entrepreneurial motives. Journal of Small Business Management, 54(4), 1015-1037. https://doi.org/10.1111/jsbm.12229

Scott, M. G., \& Twomey, D. F. (1998). The long-term supply of entrepreneurs: Students' career aspirations in relation to entrepreneurship. Journal of Small Business Management, 10, 5-12.

Sena, A., Freitas, C., Souza, P. F., Carneiro, F., Alpino, T., Pedroso, M., Corvalan, C., \& Barcellos, C. (2018). Drought in the semiarid region of Brazil: Exposure, vulnerabilities and health impacts from the perspectives of local actors. PLoS Currents 1. https://doi.org/10.1371/currents.dis.c226851ebd64290e619a4d1ed79c8639

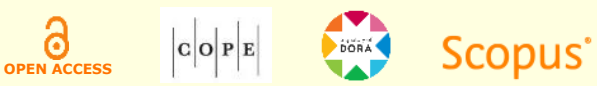


Shaw, E., \& Carter, S. (2007). Social entrepreneurship: Theoretical antecedents and empirical analysis of entrepreneurial processes and outcomes. Journal of Small Business and Enterprise Development, 14(3), 418-434. https://doi.org/10.1108/14626000710773529

Short, J. C., Moss, T. W., \& Lumpkin, G. T. (2009). Research in social entrepreneurship: Past contributions and future opportunities. Strategic Entrepreneurship Journal, 3(2), 161-194. https://doi.org/10.1002/sej.69

Shumate, M., Atouba, Y., Cooper, K. R., \& Pilny, A. (2014). Two paths diverged: Examining the antecedents to social entrepreneurship. Management Communication Quarterly, 28(3), 404-421. https://doi.org/10.1177/0893318914538561

Subramaniam, M., \& Youndt, M. A. (2005). The influence of intellectual capital on the types of innovative capabilities. Academy of Management Journal, 48(3), 450-463. https://doi.org/10.5465/amj.2005.17407911

Thompson, J., Alvy, G., \& Lees, A. (2000). Social entrepreneurship - a new look at the people and the potential. Management Decision, 38(5), 328-338. https://doi.org/10.1108/00251740010340517

Wry, T., \& York, J. G. (2017). An identity-based approach to social enterprise. Academy of Management Review, 42(3), 437-460. https://doi.org/10.5465/amr.2013.0506

Yin, R. K. (1981). The case study as a serious research strategy. Knowledge, 3(1), 97-114. https://doi.org/10.1177/107554708100300106

Yin, R. K. (2002). Case study research: Design and methods. Thousand Oaks, CA: Sage Publications.

Yunus, M., Moingeon, B., \& Lehmann-Ortega, L. (2010). Building social business models: Lessons from the grameen experience. Long Range Planning, 43(2-3), 308-325. https://doi.org/10.1016/j.lrp.2009.12.005

Zahra, S. A., Gedajlovic, E., Neubaum, D. O., \& Shulman, J. M. (2009). A typology of social entrepreneurs: Motives, search processes and ethical challenges. Journal of Business Venturing, 24(5), 519-532. https://doi.org/10.1016/j.jbusvent.2008.04.007

Zahra, S. A., Rawhouser, H. N., Bhawe, N., Neubaum, D. O., \& Hayton, J. C. (2008). Globalization of social entrepreneurship opportunities. Strategic Entrepreneurship Journal, 2(2): 117-131. https://doi.org/10.1002/sej.43

Zawislak, P. A., Alves, A. C., Tello-Gamarra, J., Barbieux, D., \& Reichert, F. M. (2012). Innovation capability: From technology development to transaction capability. Journal of Technology Management $\mathcal{E}$ Innovation, 7(2), 14-27. http://dx.doi.org/10.4067/S0718-27242012000200002

\section{Authors' contributions}

1st author: conceptualization (lead), data curation (equal), formal analysis (equal), funding acquisition (equal), investigation (lead), methodology (lead), project administration (equal), supervision (equal), validation (equal), visualization (equal), writing-original draft (lead), writing-review \& editing (lead).

2nd author: conceptualization (supporting), data curation (equal), formal analysis (supporting), funding acquisition (equal), investigation (supporting), methodology (supporting), project administration (equal), supervision (equal), validation (equal), visualization (equal), writing-original draft (supporting), writing-review \& editing (supporting).

\section{Authors}

\section{Leandro da Silva Nascimento}

Universidade Federal de Pernambuco, Programa de Pós-Graduação em Administração Av. Prof. Moraes Rego, 1235, Cidade Universitária, 50670-901, Recife, PE, Brazil

lesnasc@gmail.com

(iD) https://orcid.org/0000-0003-0981-1718

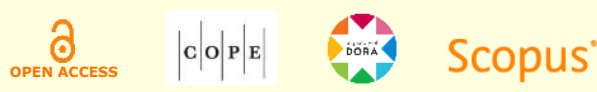




\section{Viviane Santos Salazar}

Universidade Federal de Pernambuco, Programa de Pós-Graduação em Administração Av. Prof. Moraes Rego, 1235, Cidade Universitária, 50670-901, Recife, PE, Brazil viviane_salazar@yahoo.com.br

iD https://orcid.org/0000-0001-7046-3703 